be a unique adventure into medical literature.

Around the central figure of Dr. Fetchquick, a busy, capable and not infallible general practitioner, moves a parade of real live people, each the receptacle of a disease of body or mind, each living out in the compass of a few pages, the natural history of his or her complaint. One chapter tells the story of the patient with acute nephritis which fails to resolve and which insidiously leads to death in uraemia. In another, entitled ' Study in Tact,' gay Sir Edgar Edgoose, Bart., is found to have the rash of secondary syphilis and a wife who is three months pregnant. Cured of this disease the same unfortunate later develops a refractory duodenal ulcer. The hysteric, the neurotic and the depressive all visit the doctor's surgery the evening he is to take his wife to the cinema; the depressive receives shorter shrift than is perhaps his due and is found dead, head in oven, soon after. Admirably, the narrative carries through to the Coroner's inquest. These are but a random sample of the many entertaining stories that fill the book.

The pathology of each condition is described in simple terms in a series of asides "while the patient removes his trousers.' Many leading symptoms and signs are piquantly portrayed in line by Miss Treadgold.

Style is easy; a sense of informality pervades the book and robs it of serious literary merit. But it does not pretend to that. It is rich in the author's philosophy which has that generous humanity so characteristic of the physician-philosopher. This is no book for the sophisticated or the high-powered. Rather it is for the 'medico'-student, nurse, technician or doctor to whom the drama of disease is incomplete without the players.

H.K.

\section{CURRENT CONCEPTS IN DIGITALIS THERAPY}

By B. Lown, M.D., and S. A. Levine, M.D. Pp. ix +164 , with 21 illustrations. London: J. \& A. Churchill Ltd. 1955. 25 s.

Any publication associated with the name of Dr. Samuel Levine is always well worth careful reading, for it will not be over-burdened with unintelligible figures and will contain the results of much thought and abundant common sense.

In this book Lown and Levine review all the problems connected with digitalis therapy and commendably cut through the dead wood of some of the supposed actions of digitalis. The reviewer is always sorry for students trying to memorize lists of multiple digitalis effects which appear to be quite disconnected. The emphasis on the important effects, both therapeutic and toxic, is here clearly stated with illustrative case reports. There are excellent chapters concerned with electrolytes and digitalis, and on the treatment of paroxysmal atrial tachycardia with block.

The final chapter describing a digitalis tolerance test is not so satisfactory as the rest of the book, and the rapidly destroyed substance, acetyl stro- phanthidin, used is not obtainable in Great Britain.

Twenty-five shillings for a book of 164 pages is expensive, but as most doctors prescribe digitalis several times a day, it is a small price to pay in order to obtain a proper understanding of its use.

R.D.

\section{CORONARY HEART DISEASE IN YOUNG ADULTS}

By. Menard M. Gertler, M.D., and Paul D. White, M.D. Pp. xviii +218 , illustrated. London: Geoffrey Cumberlege. 1954. 408.

This book is an attempt by Dr. Menard Gertler, Dr. Paul White and their fellow workers at Harvard to establish the constitutional and environmental factors which lead to coronary occulsion. Their results are largely negative, but they should provide many suggestions for further studies and a wholesome corrective to those who believe they already know most of the answers.

They have chosen for investigation 100 patients who had survived, for at least six months, a coronary occlusion before the age of 40 and have subjected them to an intensive clinical, psychological, biochemical and anthropometric study. The patients are compared with a group of controls selected by the matched pair technique. The authors suggest that both psychological and biochemical findings may be largely determined by body-build and that the 'young coronary candidate' is a male 'endomorphic mesomorph' with a family history of cardiovascular disease, a raised serum cholesterol and uric acid and a high salivary oxidation reduction potential. The practical value of these criteria is greatly lessened by the very wide overlap with the matched controls.

There is much valuable information about many aspects of coronary artery disease in this book which has a good index and a useful list of references. It suffers, inevitably, from the inherent difficulty of investigating the cause of a disease whose first clinical manifestation may be the product of many years of pathological change. One cannot help hoping that the ' coronary candidate' will not be recognized too readily before we have a simple and reliable means of helping him. J.W.L.

\section{AMPHETAMINE IN CLINICAL MEDICINE ACTION AND USES}

By W. R. BretT, M.R.C.S., L.R.C.P., F.R.S.I., LeONARD H. Howells, B.Sc., M.D., F.R.C.P., and A. D. Macdonald, M.A., M.D., M.Sc. Pp. 78. Edinburgh: E. \& S. Livingstone Ltd. 1955. 7s. 6d.

With the widespread use of this drug in recent years a small well-written book such as this is most welcome. The information given has been carefully selected and the references confined to those 